\title{
VATER/VACTERL Association: Evidence for the Role of Genetic Factors
}

\author{
H. Reutter ${ }^{a, b} \quad$ M. Ludwig ${ }^{c}$ \\ ${ }^{a}$ Institute of Human Genetics, ${ }^{b}$ Department of Neonatology, Children's Hospital and ${ }^{\mathrm{c} D e p a r t m e n t}$ of Clinical \\ Chemistry and Clinical Pharmacology, University of Bonn, Bonn, Germany
}

\section{Key Words}

Animal models · Candidate genes - Multiplex families •

Twin studies $\cdot$ VATER/VACTERL association

\begin{abstract}
The VATER/VACTERL association is typically defined by the presence of at least 3 of the following congenital malformations: Vertebral anomalies, Anal atresia, Cardiac malformations, Tracheo-Esophageal fistula, Renal anomalies, and Limb abnormalities. The involvement of genetic factors in the development of this rare association is suggested by reports of familial occurrence, the increased prevalence of component features among first-degree relatives of affected individuals, high concordance rates among monozygotic twins, chromosomal (micro-)aberrations or single gene mutations in individuals with the VATER/VACTERL phenotype, as well as murine knock-out models. Despite substantial efforts over the past decade, the genetic etiology of the VATER/ VACTERL association in most instances remains elusive. The application of new genomic technologies such as high-resolution copy number variation studies or next-generation exome sequencing might lead to the identification of some of these causes.

Copyright $\odot 2012$ S. Karger AG, Basel
\end{abstract}

(C) 2012 S. Karger AG, Basel

$1661-8769 / 13 / 0042-0016 \$ 38.00 / 0$

Fax +4161306 1234

E-Mail karger@karger.ch

www.karger.com
Accessible online at:

www.karger.com/msy
The VATER/VACTERL association acronym (OMIM 192350) refers to the rare, non-random co-occurrence of Vertebral defects, Anorectal malformations, Cardiac defects, Tracheo-Esophageal fistula with or without esophageal atresia, Renal malformations, and Limb defects [Quan and Smith, 1973]. At the time of writing, no diagnostic biomarkers are available, and commonly used clinical diagnosis requires the presence of at least 3 major component features (CFs) [Quan and Smith, 1973; Czeizel and Ludányi, 1985]. Population based epidemiological studies in Europe and the United States reported different birth prevalences [Khoury et al., 1983; Czeizel and Ludányi, 1985; Botto et al., 1997]. While Khoury et al. [1983] described the prevalence among infants to be 1 in 10,000 by evaluating approximately 300,000 live or stillborn infants, Botto et al. [1997] found a lower prevalence of 1 in 40,000 by looking at almost 10,000,000 live or stillborn infants using the multiple congenital anomaly data base of the International Clearinghouse for Birth Defects Monitoring Systems [Mastroiacovo, 1991; International Clearinghouse for Birth Defects Monitoring Systems, 1994]. Although in most instances genetic determinants have yet to be identified, various lines of evidence, such as the finding of familial occurrence, an increase in the prevalence of CFs in first-degree relatives of affected in- 
dividuals, high concordance rates (CRs) among monozygotic (MZ) twins, chromosomal (micro-)aberrations or the presence of single gene mutations in individuals with the VATER/VACTERL phenotype, as well as murine knock-out models point to the importance of genetic factors in the etiology of this non-random congenital multisystem defect. In the following review we summarize these various lines of evidence and discuss their importance.

\section{Familial Occurrences}

Recent independent reports by Solomon et al. [2010] and Bartels et al. [2012a] describe an increased prevalence of CFs in first-degree relatives of patients with VATER/ VACTERL association. Including these 2 studies, a total of 19 families with 1 member exhibiting 3 or more CFs, and an additional relative presenting at least $1 \mathrm{CF}$, has been reported in the literature, supporting the hypothesis of an underlying genetic susceptibility in at least these families [Arrington et al., 2010; Solomon et al., 2010; Chung et al., 2011; Bartels et al., 2012a; Hilger et al., 2012]. Both Solomon et al. [2010] and Bartels et al. [2012a] further report on families in which second-degree relatives of patients present with various types and number of CFs, which might be explained by reduced penetrance and variable expressivity or an underlying multifactorial mode of inheritance. A limitation of both studies in terms of the estimation of genetic influences on the development of the VATER/VACTERL association is the lack of offspring in their investigated patient cohorts. Although the total number of familial reports is small, certain CFs as vertebral defects might be underdiagnosed among otherwise healthy relatives, making a complete estimation of the distribution of CFs among first or second-degree relatives of patients with VATER/VACTERL association impossible.

\section{Twin Studies}

Apart from the observation of familial occurrences, twin studies provide an efficient method to untangle the influences of genetic and environmental factors on a trait [Allen et al., 1967; Risch, 2001]. While MZ twins are essentially genetically identical, dizygotic (DZ) twins share on average half of their genes. Assuming a similar intrauterine environment among $\mathrm{MZ}$ and $\mathrm{DZ}$ twins, a higher $\mathrm{CR}$ among $\mathrm{MZ}$ twins (as compared to DZ twins) would point to a genetic susceptibility [Risch, 2001]. In the only twin study published at the time of writing, Bartels et al. [2012b] identified a total of 69 twin pairs from their own patient cohorts as well as an intensive review of the literature and re-evaluated the status of zygosity, concordance, and malformation of these twins. Comparison of CRs between $\mathrm{MZ}$ and DZ twin pairs showed slightly higher pair- and proband-wise CRs for DZ compared to MZ twin pairs [Bartels et al., 2012b]. Other than through environmental factors, the high number of MZ discordant twin pairs might be explained by postzygotic somatic or de novo germline mutations [Kondo et al., 2002] or epigenetic events occurring early in embryogenesis [Yamazawa et al., 2008].

\section{Chromosomal Anomalies and Single Gene Mutations}

In the past, chromosomal anomalies were repeatedly reported and have been suggested to be susceptibility factors for the development of the VATER/VACTERL association. To date, cytogenetic and molecular analyses have revealed chromosomal (micro-)aberrations in at least 11 patients with the full clinical picture of the VATER/VACTERL association. These include: (i) deletions of $5 \mathrm{q} 11.2$ [de Jong et al., 2010], 6q [McNeal et al., 1977], 7q35qter [Zen et al., 2010], distal 13q [Walsh et al., 2001], and 20q13.33 [Solomon et al., 2011]; (ii) duplication of 9q [Aynaci et al., 1996] and 22q11.21 [Schramm et al., 2011]; (iii) supernumerary der(22) syndrome [Prieto et al., 2007]; (iv) mosaicism for supernumerary ring chromosome 12 [Cinti et al., 2001] or 18 [van der Veken et al., 2010], and (v) partial monosomy 16p13.3pter/partial trisomy 16q22qter [Yamada et al., 2009].

In a few cases, distinct gene mutations have been reported, with mostly VATER/VACTERL-like phenotypes. As these mutations were only found in single patients, their contribution to the development of these phenotypes remains elusive. In a female patient with tetralogy of Fallot, bilateral hydronephrosis and hydroureters, anorectal malformation, and inter-phalangeal joints of her 4 th and 5th toes, resembling a VATER/VACTERL-like phenotype, Garcia-Barceló et al. [2008] identified a heterozygous 21-bp de novo deletion in HOXD13, encoding a sonic hedgehog $(\mathrm{SHH})$ downstream target. However, no other patient with VATER/VACTERL association has yet been reported to carry disease-causing mutations in HOXD13. In another male patient with a VATER/VACTERL-hydrocephalus phenotype, presenting with bilat- 
eral thumb hypoplasia, radial deviation of the hands, more marked on the right side, severe macrocephaly, and ventriculomegaly, a heterozygous de novo PTEN missense mutation was found [Reardon et al., 2001]. While this association may be purely coincidental, it could also be suggestive of an implication of different growth-controlling pathways that involve $\mathrm{SHH}$ and the signal transduction of HOX and phosphatidylinositol 3'-kinase [Hill and $\mathrm{Wu}, 2009]$ in the expression of VATER/VACTERL CFs. This idea is supported by an observation made by Arrington et al. [2010] who detected haploinsufficiency of the LPP gene in a patient with VATER/VACTERL phenotype who was born with tetralogy of Fallot, rib anomalies, hypospadias, small kidneys and esophageal atresia. LPP codes for the LIM domain containing preferred translocation partner in lipoma, which has been shown to bind PEA3 (polyomavirus enhancer activator 3 homo$\log$ ), an ETS domain transcription factor involved in the SHH signaling pathway [Guo et al., 2006]. However, LPP gene analysis did not detect any deleterious sequence changes in 70 additional patients with VATER/VACTERL phenotype [Hernández-García et al., 2012], indicating that $L P P$ mutations are not a common finding in the VATER/VACTERL association.

Another cause of the VATER/VACTERL phenotype is mutations in the Fanconi anemia complementation group [Holden et al., 2006]. Faivre et al. [2005] found in over 200 patients with Fanconi anemia, that approximately 5\% were judged to have a VATER/VACTERL phenotype. Although Fanconi anemia seems to be a rare cause of expression of the VATER/VACTERL phenotype, it is an important differential diagnosis as the condition is associated with a high morbidity and mortality. The 3-hydroxy-3-methylglutaryl-CoA lyase deficiency has been described co-occurring in a boy with VATER/VACTERL association [Al-Essa et al., 1998]. As this report is the only described co-occurrence between a 3-hydroxy3-methylglutaryl-CoA lyase deficiency and the VATER/ VACTERL association, it most likely represents a coincidence rather than a causal relationship.

Besides the classical VATER/VACTERL association, an associated condition presents with hydrocephalus. In view of its X-linked transmission, it is termed X-linked VATER/VACTERL-hydrocephalus (or VACTERL-H), which can be caused by mutations in the ZIC3 gene. The same gene has been described to be responsible for the Xlinked visceral heterotaxy-1 [Wessels et al., 2010; Chung et al., 2011]. Wessels et al. [2010] reported a male infant with a ZIC3 polyalanine expansion associated with VATER/VACTERL phenotype without hydrocephalus. A 4-generation family with several affected members, showing a ZIC3 deletion, was reported by Chung et al. [2011], with 1 case presenting with the full picture of the VATER/VACTERL association.

\section{Animal Models}

Animal models or knock-out mice exhibiting a VATER/VACTERL-like phenotype are rare. Genetically engineered mice with mutations in genes of the Shh signaling cascade [Kim et al., 2001] or with a heterozygous ethylnitrosourea-induced mutation in the Pcsk5 (proprotein convertase subtilisin/kexin type 5) gene [Szumska et al., 2008] show VATER/VACTERL-like features, but do not exhibit the full picture of the human VATER/VACTERL phenotype. Nevertheless, their expression in mice suggests an involvement of these genes and their pathways in the etiology of CFs occurring in humans. Furthermore, the recent observation of a female cat showing the spontaneous pentad VACRL of the VATER/VACTERL association [Moura et al., 2010] points to a common genetic background of these multiple congenital abnormalities in mammals.

\section{Conclusion}

The involvement of genetic factors in the etiology of the VATER/VACTERL association is suggested by various independent reports and studies in humans and animal models. Hence, a combined application of new genomic technologies such as high-resolution copy number variation studies or next-generation exome sequencing might lead to the identification of genes causally related to the VATER/VACTERL association in humans and will allow a better understanding of this complex and severe co-occurrence of anomalies.

\section{Acknowledgements}

H.R. and M.L. are members of the 'Network for the Systematic Investigation of the Molecular Causes, Clinical Implications, and Psychosocial Outcome of Congenital Uro-Rectal Malformations (CURE-Net)' which is supported by a research grant (01GM08107) from the German Federal Ministry of Education and Research (Bundesministerium für Bildung und Forschung, BMBF).
Reutter/Ludwig 


\section{References}

-Al-Essa M, Rashed M, Ozand PT: 3-Hydroxy-3methylglutaryl-CoA lyase deficiency in a boy with VATER association. J Inher Metab Dis 21:443-444 (1998).

-Allen G, Harvald B, Shields J: Measures of twin concordance. Acta Genet Stat Med 17:475481 (1967).

- Arrington CB, Patel A, Bacino CA, Bowles NE: Haploinsufficiency of the LIM domain containing preferred translocation partner in lipoma ( $L P P)$ gene in patients with tetralogy of Fallot and VACTERL association. Am J Med Genet A 152A:2919-2923 (2010).

-Aynaci FM, Celep F, Karaguzel A, Baki A, Yildiran A: A case of VATER association associated with 9qh+. Genet Couns 7:321-322 (1996).

- Bartels E, Jenetzky E, Solomon BD, Ludwig M, Schmiedeke E, et al: Inheritance of the VATER/VACTERL association. Pediatr Surg Int 28:681-685 (2012a).

Bartels E, Schulz AC, Mora NW, Pineda-Alvarez DE, Wijers $\mathrm{CH}$, et al: VATER/VACTERL association: identification of seven new twin pairs, a systematic review of the literature, and a classical twin analysis. Clin Dysmorphol 21:191-195 (2012b).

Botto LD, Khoury MJ, Mastroiacovo P, Castilla EE, Moore CA, et al: The spectrum of congenital anomalies of the VATER association: an international study. Am J Med Genet 71: 8-15 (1997).

-Chung B, Shaffer LG, Keating S, Johnson J, Casey B, Chitayat D: From VACTERL-H to heterotaxy: variable expressivity of ZIC3-related disorders. Am J Med Genet A 155A:11231128 (2011).

-Cinti R, Priolo M, Lerone M, Gimelli G, Seri M, et al: Molecular characterisation of a supernumerary ring chromosome in a patient with VATER association. J Med Genet 38:E6 (2001).

Czeizel A, Ludányi I: An aetiological study of the VACTERL-association. Eur J Pediatr 144: 331-337 (1985).

de Jong EM, Douben H, Eussen BH, Felix JF, Wessels MW, et al: $5 q 11.2$ deletion in a patient with tracheal agenesis. Eur J Hum Genet 18:1265-1268 (2010).

-Faivre L, Portnoï MF, Pals G, Stoppa-Lyonett D, Le Merrer M, et al: Should chromosome breakage studies be performed in patients with VACTERL association? Am J Med Genet A 137:55-58 (2005).

- Garcia-Barceló MM, Wong KK, Lui VC, Yuan ZW, So MT, et al: Identification of a HOXD13 mutation in a VACTERL patient. Am J Med Genet A 146A:3181-3185 (2008).
Guo B, Sallis RE, Greenall A, Petit MM, Jansen $\mathrm{E}$, et al: The LIM domain protein LPP is a coactivator for the ETS domain transcription factor PEA3. Mol Cell Biol 26:45294538 (2006).

Hernández-García A, Brosens E, Zaveri HP, de Jong EM, Yu Z, et al: Contribution of LPP copy number and sequence changes to esophageal atresia, tracheoesophageal fistula, and VACTERL association. Am J Med Genet A 158A:1785-1787 (2012).

-Hilger A, Schramm C, Draaken M, Mughal SS, Dworschak G, et al: Familial occurrence of the VATER/VACTERL association. Pediatr Surg Int 28:725-729 (2012).

- Hill R, Wu H: PTEN, stem cells, and cancer stem cells. J Biol Chem 284:11755-11759 (2009).

Holden ST, Cox JJ, Kesterton I, Thomas NS, Carr C, Woods CG: Fanconi anaemia complementation group B presenting as $\mathrm{X}$ linked VACTERL with hydrocephalus syndrome. J Med Genet 43:750-754 (2006).

International Clearinghouse for Birth Defects Monitoring Systems: Annual Report 1992. Rome, International Center for Birth Defects (1994).

Khoury MJ, Cordero JF, Greenberg F, James LM, Erickson JD: A population study of the VAC TERL association: evidence for its etiologic heterogeneity. Pediatrics 71:815-820 (1983).

Kim PC, Mo R, Hui CC: Murine models of VACTERL syndrome: role of sonic hedgehog signaling pathway. J Pediatr Surg 36:381-384 (2001).

Kondo S, Schutte BC, Richardson RJ, Bjork BC, Knight AS, et al: Mutations in IRF6 cause Van der Woude and popliteal pterygium syndromes. Nat Genet 32:285-289 (2002).

Mastroiacovo P: An ICBDMS collaborative study: Monitoring multimalformed infants. Int J Risk Safety Med 2:255-270 (1991).

McNeal RM, Skoglund RR, Francke U: Congenital anomalies including the VATER association in a patient with del(6)q deletion. J Pediatr 91:957-960 (1977).

Moura E, Cirio SM, Villanova JA Jr: VACTERL association in a cat. Am J Med Genet A 152A:777-780 (2010).

-Prieto JC, Garcia NM, Elder FF, Zinn AR, Baker LA: Phenotypic expansion of the supernumerary derivative (22) chromosome syndrome: VACTERL and Hirschsprung's disease. J Pediatr Surg 42:1928-1932 (2007).

$\checkmark$ Quan L, Smith DW: The VATER association. Vertebral defects, anal atresia, T-E fistula with esophageal atresia, radial and renal dysplasia: a spectrum of associated defects. J Pediatr 82:104-107 (1973).

-Reardon W, Zhou XP, Eng C: A novel germline mutation of the PTEN gene in a patient with macrocephaly, ventricular dilatation, and features of VATER association. J Med Genet $38: 820-823$ (2001).
Risch N: The genetic epidemiology of cancer: interpreting family and twin studies and their implications for molecular genetic approaches. Cancer Epidemiol Biomarkers Prev 10:733-741 (2001).

-Schramm C, Draaken M, Bartels E, Boemers TM, Aretz S, et al: De novo microduplication at 22q11.21 in a patient with VACTERL association. Eur J Med Genet 54:9-13 (2011).

-Solomon BD, Pineda-Alvarez DE, Raam MS, Cummings DA: Evidence for inheritance in patients with VACTERL association. Hum Genet 127:731-733 (2010).

-Solomon BD, Pineda-Alvarez DE, Hadley DW, Keaton AA, Agochukwu NB, et al: De novo deletion of chromosome $20 \mathrm{q} 13.33$ in a patient with tracheo-esophageal fistula, cardiac defects and genitourinary anomalies implicates GTPBP5 as a candidate gene. Birth Defects Res A Clin Mol Teratol 91:862-865 (2011).

-Szumska D, Pieles G, Essalmani R, Bilski M, Mesnard D, et al: VACTERL/caudal regression/Currarino syndrome-like malformations in mice with mutations in the proprotein convertase Pcsk5. Genes Dev 22:14651477 (2008).

van der Veken LT, Dieleman MM, Douben H, van de Brug JC, van de Graaf R, et al: Low grade mosaic for a complex supernumerary ring chromosome 18 in an adult patient with multiple congenital anomalies. Mol Cytogenet 3:13 (2010).

-Walsh LE, Vance GH, Weaver DD: Distal 13q deletion syndrome and the VACTERL association: case report, literature review, and possible implications. Am J Med Genet 98:137144 (2001).

Wessels MW, Kuchinka B, Heydanus R, Smit BJ, Dooijes D, et al: Polyalanine expansion in the ZIC3 gene leading to X-linked heterotaxy with VACTERL association: a new polyalanine disorder? J Med Genet 47:351-355 (2010).

-Yamada K, Uchiyama A, Arai M, Kubodera K, Yamamoto Y, et al: Severe upper airway stenosis in a boy with partial monosomy 16p13.3pter and partial trisomy 16q22qter. Congenit Anom (Kyoto) 49:85-88 (2009).

- Yamazawa K, Kagami M, Fukami M, Matsubara $\mathrm{K}$, Ogata T: Monozygotic female twins discordant for Silver-Russell syndrome and hypomethylation of the H19-DMR. J Hum Genet 53:950-955 (2008).

Zen PR, Riegel M, Rosa RF, Pinto LL, Graziadio C, et al: Esophageal stenosis in a child presenting a de novo $7 \mathrm{q}$ terminal deletion. Eur $\mathrm{J}$ Med Genet 53:333-336 (2010). 